Satriya Pranata, Herlina Wulandari, Pengaruh Terapi Pijat Terhadap Tingkat Kadar Glukosa Darah Pada Pasien Dengan Diabetes Mellitus : Literature Review

\title{
PENGARUH TERAPI PIJAT TERHADAP TINGKAT KADAR GLUKOSA DARAH PADA PASIEN DENGAN DIABETES MELLITUS : LITERATURE REVIEW
}

\author{
Satriya Pranata ${ }^{1}$ \\ Faculty of Nursing and Health Sciences, Muhammadiyah University of Semarang \\ Corresponding author E-mail : satriya.pranata@unimus.ac.id \\ Herlina Wulandari ${ }^{2}$ \\ Faculty of Nursing and Health Sciences, Muhammadiyah University of Semarang
}

\begin{abstract}
ABSTRAK
Latar belakang: penderita diabetes melitus terus mengalami peningkatan tiap tahunnya. Laporan menunjukkan bahwa terapi pijat merupakan terapi komplementer yang digemari di indonesia serta memiliki banyak manfaat.

Tujuan: menggali lebih dalam mengenai pengaruh terapi pijat terhadap tingkat kadar glukosa darah pada pasien dengan diabetes melitus.

Metode: Pencarian artikel dilakukan menggunakan Science Direct, Medline, Google Search dan Pro Quest untuk menemukan artikel sesuai kriteria inklusi dan ekslusi. Artikel yang sesuai dengan kriteria yang ditetapkan penulis dianalisis, ditentukan level dari evidancenya, diekstraksi kemudian disintesis.

Hasil: terapi pijat secara signifikan mampu mengontrol kadar glukosa darah pada pasien anakanak dengan diabetes melitus $P$ value $<0,0001$. Faktor yang mempengaruhi pasien menggunakan pengobatan komplementer adalah gender dengan $P$ value $=0.049$, pemasukan rumah tangga $P=0.048$ dan frekuensi kontrol gula darah $P=0.036$. Swedish massage terbukti efektif memberikan efek penurunan kadar glukosa darah pada anak dengan DM nilai $P=0.00$. sampel menggunakan pengobatan herbal mencapai $100 \%$. Intervensi mind body $94,2 \% .100 \%$. Sampel mempercayai bahwa obat herbal dapat menurunkan kadar glukosa darah dan dapat mengatasi gejala DM 35,7\%. Terdapat signifikansi kadar glukosa darah dan laktat sebelum dan sesudah pijat dengan nilai $\mathrm{P}<0.05$. Terdapat penurunan level ansietas dan glukosa darah sebelum dan sesudah dilakukan intervensi pijat dengan nilai $P 0.00$.

Kesimpulan: terapi pijat merupakan terapi komplementer yang digemari. Hasil penelitian belum dapat digeneralisasi. Perlu dilakukan penelitian lanjutan
\end{abstract}

Kata Kunci : Diabetes Melitus, Terapi Pijat, Glukosa Darah

\section{ABSTRACT}

Background: people with diabetes mellitus are continue to increase every year. Studies indicate that massage therapy is a complementary therapy which is popular and has many functions in Indonesia.

Purpose: to explore more deeply about the effect of massage therapy on blood glucose levels in patients with diabetes mellitus.

Method: The article search was carried out using Science Direct, Medline, Google Search and Pro Quest to find articles according to the inclusion and exclusion criteria. Articles those meet with criteria from researcher were analized, determined level of evidence, extracted, further synthesized.

Results: massage therapy was significantly to control blood glucose levels in pediatric patients with diabetes mellitus $P$ value $<0,0001$. Factors affecting patients using complementary medicine were gender with $P$ value $=0.049$, household income $P=0.048$ and frequency of blood sugar control $P=0.036$. Swedish massage was proven to be effective in reducing the blood glucose level for DM children with $P$ value $=0.00$. Samples who using herbal treatments reach $100 \%$. Mind body intervention 94.2\%. 100\% Samples believe that herbal medicines can reduce blood glucose levels and can overcome DM symptoms by $35.7 \%$. There is a significance level of blood glucose and lactate before and after massage with a $P$ value $<0.05$. There was a decrease in anxiety and blood glucose levels before and after the massage intervention with a $P$ value of 0.00 . Conclusion: massage therapy is included into a popular complementary therapy. The research of study cannot be generalized. Further research in the future are needed. 
Keywords : diabetes mellitus, massage therapy, blood glucose

\section{PENDAHULUAN}

Diabetes Mellitus (DM) merupakan salah satu penyakit kronis yang melanda seluruh belahan dunia hingga saat ini. Total pasien Diabetes Mellitus (DM) di seluruh dunia adalah 425 juta orang, yang meningkat $48 \%$ daripada setiap tahun sebelumnya. Prediksi pada 2045, populasi akan meningkat hingga 629 juta. Peningkatan ini juga terjadi di Indonesia. Pasien DM di Indonesia pada tahun 2017 adalah 159 juta, jumlah ini meningkat $15 \%$ dari tahun sebelumnya, dan diperkirakan pada tahun 2045, jumlahnya akan bertambah menjadi 183 juta, (IDF, 2017).

Dengan bertambahnya jumlah penderita DM setiap tahunnya, tantangan tenaga kesehatan khususnya perawat untuk mensikapi kondisi ini tentunya semakin besar karena masalah yang timbul berdasarkan respon tubuh juga akan semakin kompleks, (Pranata \& Huang, 2020). Selama ini penanganan pasien DM masih dilakukan berdasarkan konteks kolaborasi farmakologi, padahal perawat memiliki intervensi mandiri yaitu terapi komplementer yang diharapkan menjadi salah satu solusi penanganan peningkatan glukosa darah pasien DM.

Salah satu terapi komplementer yang sedang berkembang saat ini adalah terapi pijat (massage therapy). Penelitian menunjukkan bahwa tindakan

komplementer seperti terapi pijat memiliki banyak manfaat, terapi pijat dapat meningkatkan mood pasien setelah melakukan operasi jantung terbuka (Babae, 2012). Terapi pijat mampu menurunkan tingkat depresi pasien penderita HIV (Polland, 2013). Back massage dapat menurunkan ansietas, meningkatkan aliran darah pada pasien CHF (congestif heart failure) (Chen 2013). Penelitian yang dilakukan oleh (Kashaninia, et al, 2011) menunjukkan bahwa swedish massage dapat mengontrol kadar glukosa darah pada pasien diabetes melitus. Penelitian yang dilakukan oleh (Finch, et al, 2007) menunjukkan bahwa massage therapy berefek positif terhadap potensial pergerakan, menurunkan insiden ulcer neuropati pada diabetes melitus.

Dengan banyaknya manfaat yang dilaporkan mengenai terapi pijat maka penulis tertarik untuk menggali lebih dalam mengenai pengaruh terapi pijat terhadap tingkat kadar glukosa darah pada pasien dengan diabetes melitus.

\section{METODE PENELITIAN}

1. Design

Jenis design penelitian yang dimasukkan didalam literatur review adalah RCT, quasy eksperiment, Two occasions in a counter balance dan Cross sectional design. Jenis design penelitian ini dirasa sudah dapat menjawab pertanyaan klinis yang sudah ditentukan sejak awal.

2. Kriteria inklusi dan ekslusi

a. Tipe study

Tipe study yang akan direview adalah semua jenis penelitian yang menggunakan terapi pijat untuk menurunkan kadar glukosa darah pada pasien dengan diabetes melitus.

b. Tipe partisipan/responden

Partisipan yang ditentukan untuk di review tidak dibatasi secara umur maupun tipe diabetesnya. Semua jenis partisipan baik anakanak, dewasa maupun lansia dimasukkan sebagai partisipan dalam literature review.

c. Tipe intervensi Intervensi yang dimasukkan dalam kriteria inklusi adalah semua jenis intervensi terapi pijat yang dilakukan untuk menurunkan tingkat kadar glukosa darah pada pasien dengan diabetes melitus.

d. Tipe outcome yang diukur Tipe outcome yang diukur hanya berbatas pada pengaruh terapi pijat terhadap tingkat kadar glukosa darah pada pasien dengan diabetes melitus. 
3. Strategi pencarian literature review literatur review ini dilaksanakan dengan melakukan enelusuran artikel penelitian yang sudah terpublikasi dimana populasi pasiennya adalah penderita diabetes melitus yang mendapatkan perlakuan terapi pijat dimana hasilnya mampu menurunkan kadar glukosa darah. Penelusuran dilakukan menggunakan Science direct, Medline, Google Search dan Pro-quest dengan kata kuci tiap variabel yang telah di pilih. Artikel yang ditemukan dari masing-masing pencarian kemudian dilakukan pembacaan secara cermat untuk melihat artikel mana yang memenuhi kriteria inklusi penulis untuk dijadikan sebagai literatur dalam penulisan literature review. Pencaharian dibatasi dari tahun 2000-2015 yang dapat diakses fulltext dalam format pdf dengan desain RCT dan quasy eksperiment. Setiap artikel penelitian yang terpublikasi melakukan terapi pijat serta mampu menurunkan kadar glukosa darah pada pasien diabetes melitus akan dimasukkan dalam literature review.

Strateri pencarian pada data based

Langkah pencarian artikel melalui data based

1. Massage OR Massage Therapy OR manipulation soft tissue OR soft tissue mobilization

2. Glucose OR Level OR Glucose Level

3. \#1 AND \#2

4. Metode pengkajian kualitas study

Artikel yang sesuai dengan kriteria yang ditetapkan penulis dianalisis, ditentukan level dari evidancenya sampai melakukan ekstraksi data dan sintesis. Harapannya dari banyak penelitian tersebut didapatkan sebuah kesimpulan yang nantinya menjadi dasar dalam melakukan praktek keperawatan di rumah sakit, masyarakat, maupun komunitas.
5. Cara ekstraksi data

Ekstraksi data penelitian dilakukan dengan membaca hasil dari penelitian kemudian mengambil intisari dari penelitian. Intisari dari penelitian yang diambil adalah judul penelitian, nama peneliti, metode penelitiannya, jumlah sampel dengan melihat karakteristik sampel dan berapa jumlah kelompok intervensi dan kontrol, alat yang digunakan dalam proses penelitian serta hasil akhir dari penelitian lengkap dengan nilai signifikansinya. Semua bagian-bagian tersebut dimasukkan dalam sebuah tabel agar mempermudah dalam membaca hasil ekstraksi.

\section{HASIL}

Untuk mendapatkan artikel penelitian yang dibutuhkan, penulis melakukan pencarian dengan menggunakan kata kunci. Jumlah artikel yang didapatkan serta memenuhi kriteria inklusi dan eksklusi berjumlah 7 artikel dimana 4 artikel didapatkan dari medline yang membahas mengenai Swedish 2 artikel, tactile dan termomechanical massage masing-masing 1 artikel. 3 artikel sisa lainnya didapatkan dari google search. Artikel-artikel tersebut kemudian dianalisis. Berikut merupakan daftar artikel yang di ekstraksi dalam bentuk tabel: (table ekstraksi dapat dilihat pada bagian akhir artikel).

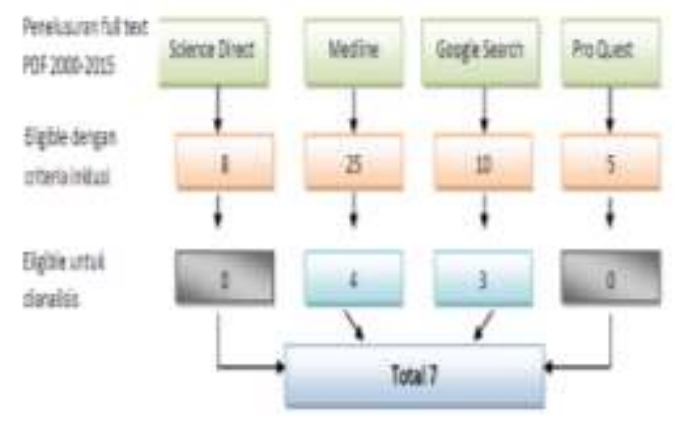

Didapatkan 7 jenis artikel, artikel yang dianalisis menggunakan metode penelitian yang beragam seperti RCT, quasy eksperiment, Two occasions in a counter balance design dan Cross sectional. Tempat penelitian dari artikel yang dapatkan juga 
beragam, Artikel pertama pengambilan data dilakukan di Iran, artikel kedua pengambilan data di singapura, artikel ketiga pengambilan data dilakukan di Iran, artikel keempat pengambilan data dilakukan di Indonesia, artikel ke lima pengambilan data dilakukan di South Korea, artikel ke enam pengambilan data dilakukan di United Kingdom dan artikel ke tujuh pengambilan datanya dilakukan di Swedia. Artikel pertama menunjukkan bahwa Swedish massage secara signifikan mampu mengontrol kadar glukosa darah pada pasien anak-anak dengan diabetes melitus $P$ value $<0,0001$. Artikel kedua menunjukkan bahwa pengobatan komplementer yang umum digunakan oleh sampel saat melakukan rawat jalan adalah suplemen gizi, obat herbal cina dan pijat. Sumber informasi pasien mengenai CAM $44,2 \%$ dari teman, dari pasangan dan keluarga $38 \%$. Faktor yang mempengaruhi pasien menggunakan pengobatan komplementer adalah gender dengan $\mathrm{P}$ value $=0.049$, pemasukan rumah tangga $P=$ 0.048 dan frekuensi control gula darah $\mathrm{P}=$ 0.036 , rekomendasi dari hasil penelitian adalah perlu dilakukan peningkatan profesionalitas tenaga kesehatan mengenai kemampuan memberikan edukasi dan pelayanan terapi komplementer pada pasien rawat jalan. Artikel ketiga dengan intervensi Swedish massage terbukti efektif memberikan efek penurunan kadar glukosa darah pada anak dengan diabetes melitus, nilai $P=0.00$. Artikel keempat dengan desain cross sectional menujukkan bahwa Favorit sampel menggunakan pengobatan herbal mencapai $100 \%$. Intervensi mind body $94,2 \% .100 \%$ Sampel mempercayai bahwa obat herbal dapat menurunkan kadar glukosa darah, menyehatkan tubuh $76,6 \%$ dan dapat mengatasi gejala DM $35,7 \%$. Informasi mengenai pengobatan herbal $98,7 \%$ di dapatkan dari relasi dan teman, $89 \%$ mengetahui sendiri, semantara informasi dari market lokal $36,4 \%$. Artikel kelima menunjukkan bahwa thermomechanical massage dapat menurunkan tekanan darah dengan $P$ value $=0.00 ;$ glukosa darah pasien dengan diabetes mengalami penurunan setelah dilakukan perlakuan dengan $\mathrm{P}$ value $=0.00$; kelompok dengan diabetes dan hipertensi signifikan mengalami penurunan tekanan darah dan penurunan kadar glukosa darah dengan $P$ value $<0.05$. Artikel ke enam menjukkan bahwa tidak ada perbedaan signifikan antar group setelah dilakukan intervensi, 9

namun terdapat penurunan selisih antar group dengan nilai $P<0.05$; intervensi pijat dapat meningkatkan perbaikan persepsi pasien dengan nilai $\mathrm{P}<0.01$; tidak ada perbedaan kandungan laktat dan glukosa darah dari intervensi dan pasiv rest intervensi. Namun terdapat signifikansi kadar glukosa darah dan laktat sebelum dan sesudah pijat dengan nilai $\mathrm{P}<0.05$. Sedangkan artikel ketujuh menunjukkan bahwa tidak ada perbedaan signifikansi level oksitosin pasien sebelum dan sesudah dilakukan intervensi tactile massage. Terdapat penurunan level ansietas dan glukosa darah sebelum dan sesudah dilakukan intervensi dengan nilai $\mathrm{P}=0.00$.

\section{PEMBAHASAN}

Hasil pencarian dengan menetapkan kriteria inklusi dan eksklusi yang ketat mempengaruhi jumlah artikel yang didapatkan. Awalnya penentuan artikel yang diambil hanya berbatas pada artikel yang menggunakan metode penelitian RCT dan quasy eksperiment, namun karena jumlah dari artikel sangat terbatas maka kriteria diturunkan, artikel dengan metode penelitian apapun akhirnya tetap dimasukkan selama tetap terkait dengan terapi pijat pada pasien diabetes melitus serta korelasi terhadap kadar glukosa darah. Setelah menurunkan kriteria berupa metode penelitian, akhirnya artikel yang didapatkan berjumlah 7 artikel. Hasil yang beragam ditunjukkan pada hasil penelitian di artikel, hasil penelitian secara umum menyebutkan bahwa terapi pijat memang terbukti signifikan mampu menurunkan kadar glukosa darah. Khasiat lain, terapi pijat mampu menurunkan tekanan darah dan menurunkan tingkat ansietas pasien dengan diabetes melitus. 
Peningkatan kadar glukosa darah, ansietas dan tingginya tekanan darah pada pasien diabetes melitus terkait dengan kerja hormon dan vaskularisasi. Pada pasien diabetes melitus, kekentalan darah meningkat karena tingginya kadar glukosa di dalam darah, akibatnya aliran darah menjadi tidak lancar sehingga memicu terjadinya hipertensi (Smeltzer \& Bare, 2008).

Pasien dengan diabetes melitus harus terus melakukan kontrol glukosa darah, kontrol diet, penyesuaian gaya hidup dikarenakan resiko komplikasi penyakit lain hingga luka yang sulit sembuh, kondisi ini akan menyebabkan terjadinya ansietas pada pasien, (Pranata, 2017). Ansietas akan memicu peningkatan hormon kortisol diikuti oleh peningkatan konversi asam amino, laktat dan piruvat di hati menjadi glukosa melalui proses glukogenesis, kondisi inilah yang menyebabkan terjadinya peningkatan kadar glukosa darah (Smeltzer \& Bare, 2008).

Terapi pijat memiliki efek fisiologis melancarkan predaran darah. Bekuan dan kekentalan darah dapat dipecah karena manipulasi pijat pada otot sehingga darah akan menjadi lancar. Lancarnya predaran darah akan memicu keluarnya hormon endorphin sehingga pasien yang dilakukan terapi pijat mengalami relaksasi (Arovah, 2010). Dengan terjadinya peningkatan relaksasi diharapkan akan diikuti juga dengan penurunan kadar glukosa di dalam darah.

Hasil penelitian pada artikel lainnya menunjukkan bahwa ternyata terapi pijat termasuk salah satu terapi komplementer alternative yang sangat diminati masyarakat di Singapura yang memiliki latar rumpun Asia sama dengan di Indonesia, itulah mengapa hasil dari penelitian yang dilakukan di Singapura dan di Indonesia cenderung memiliki kaitan yang erat yaitu minat masyarakat akan terapi komplementer seperti terapi pijat sangat digemari.

\section{Kelengkapan dan aplikasi evidence}

Artikel mengenai pelaksanaan terapi pijat terhadap kadar glukosa darah pada pasien dengan diabetes mellitus yang terpublikasi masih sedikit. Kekuatan dari evidence yang ditemukan setelah dilakukan literature review terletak pada artikel yang terpublikasi dari literature yang baik, resmi serta sudah dilakukan peer review.

\section{Kualitas evidence}

Kualitas dan bukti yang ditampilkan pada artikel sudah cukup kuat, hanya saja masih dibutuhkan penelitian lanjutan dengan desain RCT untuk membuktikan efektifitas pelaksanaan terapi pijat terhadap tingkat kadar glukosa darah pada pasien dengan diabetes melitus. Penelitian yang terbukti berkorelasi terhadap kadar glukosa darah dengan menggunakan desain RCT hanya terbukti pada sampel anak-anak. Dibutuhkan penelitian lain dengan desain RCT yang dilakukan pada orang dewasa hingga lansia.

\section{Implikasi hasil penelitian pada praktik}

Meskipun jumlah artikel yang melihat pengaruh pelaksanaan terapi pijat masih sedikit, pelaksanaan program ini memiliki peluang yang besar untuk diterapkan di tatanan klinis dan komunitas khususnya di Indonesia. Kondisi ini di dukung oleh minat masyarakat Indonesia yang tinggi pada terapi komplementer seperti pijat. Perlu dilakukan penelitian lanjutan untuk semakin menguatkan evidence.

\section{Implikasi pada penelitian lanjutan}

Perlu dilakukan penelitian lanjutan pada orang dewasa. Pemilihan lokasi pijat serta jenis pijat memiliki peran penting. Terdapat banyak jenis terapi pijat yang sudah berkembang di dunia khususnya Indonesia. Pemilihan jenis pijat yang sudah terbukti secara akademis akan lebih baik karena sudah di dukung dengan teori-teori penguat untuk menjaga pasien tetap aman saat dilakukan pijat. Perlu juga dilakukan penentuan secara teori dari tekanan yang diberikan saat melakukan pijat, perbedaan tekanan dapat dilihat dari jumlah lemak pada tubuh pasien. Semakin bayak lemak semakin besar tekanan yang harus diberikan dan sebaliknya. Pengaplikasian terapi pijat 
tergolong mudah, low cost, serta sudah didukung oleh tempat pelatihan dan instruktur pelatih yang cukup memadai. Untuk mengukur pengaruh atau efektifitas terapi akan lebih baik menggunakan metode RCT.

\section{KESIMPULAN}

Hasil literature review ini menunjukkan bahwa terapi pijat terbukti dapat menurunkan kadar glukosa darah. Khasiat lainnya adalah menurunkan ansietas dan menurunkan tekanan darah. Terapi pijat sangat digemari di Negara asia seperti Singapura dan Indonesia. Pengaplikasian terapi pijat tergolong mudah, low cost, serta sudah didukung oleh tempat pelatihan dan instruktur pelatih yang cukup memadai.

\section{SARAN}

Dengan sedikitnya hasil penelitian dengan menggunakan metode penelitian yang terbaik, penelitian selanjutnya dengan kualitas lebih baik akan memiliki efek serta dampak yang lebih besar terhadap perkembangan terapi komplementer khususnya terapi pijat dimasa depan. Jika sudah terdapat bukti baru dengan kualitas study yang lebih baik maka literature review ini dapat diperbaharui sebagai pedoman dalam pemberian pelayanan kompelementer terapi pijat untuk menurunkan kadar glukosa darah pada pada pasien dengan diabetes mellitus.

\section{DAFTAR PUSTAKA}

Arovah, NI.,(2010). Dasar-Dasar Fisioterapi Pada Cedera Olahraga. (hlm 63-74), Yogyakarta: UNY

Babae, S. Safiei, Z. Sadeghi, M.M. Nik, A.Y. Valiani, M., (2012). Effectiveness of massage therapy on the mood of patients after open-heart surgery. Iranian Journal of Nursing and Midwifery Research | February 2012 | Vol. 17 | Issue 2 (Special)

Chen, W.L. Liu, G.J. Yeh, S.H. Chiang, M.C. Fu, M.Y. Hsieh, Y.K., (2013). Effect of Back Massage Intervention on Anxiety, Comfort, and Physiologic Responses in Patients with
Congestive Heart Failure. The Journal Of Alternative And Complementary Medicine Volume 19, Number 5, 2013, pp. 464-470

Finch, P. Baskwill, A. Marincola, F and Becker, P., (2007). Changes in pedal plantar pressure variability and contact time following massage therapy. Acase study of a client with diabetic neuropathy. Journal of Bodywork and Movement Therapies. 295-301

Hemming, B. Smith, M. Graydon, J. Dyson, R.,(2000). Effects of massage on physiological restoration, perceived recovery, and repeated sports performance. $\mathrm{Br} J$ Sports Med 2000;34:109-115

Henricson, M.,(2008). Tactile Touch In Intensive Care. Nurses' preparation, patients' experiences and the effect on stress parameters. Digital version: http://hdl.handle.net/2320/1814

IDF. (2017). International Diabetes Federation Diabetes Atlas (8th ed) Brussels, Belgium: Retrieved from www.diabetesatlas.org.

Kashaninia, Z. Abedinipoor, A. Hosainzadeh, S. Sajedi, F., (2011). The Effect of Swedish Massage on Glycohemoglobin in Children with Diabetes Mellitus. Iranian Rehabilitation Journal, Vol. 9

Niswah. Chinnawong, T. Manasurakarn.,(2014).

Complementary Therapies Used Among Adult Patients with Type 2 Diabetes Mellitus in Aceh, Indonesia. Nurse Media Journal of Nursing, 4, 1, 2014, 671-687 671

Polland, R.E. Gertsik, L. Vafreau, J.T. Smith. Mirocha. J. Rao, U. Dar, E. (2013). Open-Label, Randomized, ParallelGroup Controlled Clinical Trial of Massage for Treatment of Depression in HIV-Infected Subjects. The Journal Of Alternative And Complementary Medicine Volume 19, Number 4, 2013, pp. 334-340 
Pranata, S. (2017). Perbedaan Tingkat Kecemasan Pada Pasien Diabetes Melitus Dengan Neuropati Perifer Yang Diberikan Intervensi TENS Dan Intervensi Nafas Dalam Saat Dilakukan Perawatan Ulkus Kaki Diabetik Di RSUD Kota Yogyakarta. Nurscope. Jurnal Keperawatan dan Pemikiran II.

Pranata, S., \& Huang, X.-Y. (2020). Selfmanagement Experience of Patient with Diabetes Mellitus Type 2. International Journal of Psychosocial Rehabilitation, 24(4), 7792-7801. https://doi.org/10.37200/IJPR/V24I4/P R2020969

Sajedi, F. Khashaninia, Z. Hoseimsadeh, S \& Abedinipoor, A.,(2011). How effect is Swedish Massage on Blood Glucose Level in Children with Diabetes Mellitus. Department of Nursing, School of Nursing and Midwifery

Smeltzer, S.C dan Bare, B.G. (2008). Brunner \& suddarth Textbook of medical-surgical nursing (11 th edition). Philadelphia : Lippincot William \& Wilkins.

So. C.S. Gioltli, R. Chang, T. Bae, H.J. Chang, Y. Boone, W.R. Blanks, R.H.I.,(2014). Psyological Changes Following Thermomechanical Massage in a Population of Hypertensive Patient and/or Type II Diabetis. J Vertebral Subluxation Res.-JVSR, May 3, 2014 
TABEL EKSTRAKSI DATA PENELITIAN

\begin{tabular}{|c|c|c|c|c|c|c|c|}
\hline \multirow[t]{2}{*}{ Studi/outhor } & \multirow{2}{*}{$\begin{array}{c}\text { Tempat } \\
\text { penelitian }\end{array}$} & \multirow{2}{*}{$\begin{array}{l}\text { Jumlah } \\
\text { sampel }\end{array}$} & \multirow[t]{2}{*}{ Usia } & \multicolumn{2}{|c|}{ Kelompok } & \multirow{2}{*}{$\begin{array}{c}\text { Metode penelitian/ Alat } \\
\text { ukur }\end{array}$} & \multirow[t]{2}{*}{ Outcome } \\
\hline & & & & Intervensi & Kontrol & & \\
\hline $\begin{array}{l}\text { The Effect of } \\
\text { Swedish Massage } \\
\text { on } \\
\text { Glycohemoglobin } \\
\text { in Children with } \\
\text { Diabetes Mellitus. } \\
\text { Kashaninia, et. } \\
\text { Al.,(2011) }\end{array}$ & Iran & $\begin{array}{ll}6 & \\
\text { responden. } 18 \\
\text { intervensi } \\
\text { dan } \\
\text { kontrol }\end{array}$ & 6-12 tahun & $\begin{array}{l}\text { Diberikan } \\
\text { intervensi } \\
\text { Swedish } \\
\text { massage } \\
\text { selama } 15 \\
\text { menit, } \\
\text { dilakukan } 3 \\
\text { kali dalam } \\
\text { seminggu, } \\
\text { pelaksanaan } \\
\text { dilakukan } \\
\text { selama tiga } \\
\text { bulan. }\end{array}$ & $\begin{array}{lr}\text { Tidak } & \text { dijelaskan } \\
\text { dijurnal } & \text { apa } \\
\text { intervensi } & \text { yang } \\
\text { lakukan } & \text { pada } \\
\text { krlompok kontrol }\end{array}$ & $\begin{array}{l}\text { RCT/ Kuesioner, namun } \\
\text { tidak dijelaskan secara } \\
\text { rinci mengenai alat ukur } \\
\text { yang digunakan untuk } \\
\text { mengukur } \\
\text { glycohemoglobin, namun } \\
\text { dari jurnal menunjukan } \\
\text { bahwa pengukuran } \\
\text { dilakukan dengan } \\
\text { pengukuran } \\
\text { laboratorium. }\end{array}$ & $\begin{array}{l}\text { Swedish massage secara signifikan mampu } \\
\text { mengontrol kadar glukosa darah pada } \\
\text { pasien anak-anak dengan diabetes mellitus } \\
\text { dengan } \mathrm{P} \text { value }<0,0001\end{array}$ \\
\hline $\begin{array}{l}\text { Patterns of } \\
\text { complementary } \\
\text { and alternative } \\
\text { medicine use } \\
\text { among a group of } \\
\text { patients } \\
\text { with type } 2 \\
\text { diabetes receiving } \\
\text { outpatient care in } \\
\text { Singapore. } \\
\text { Fan, et. Al.,(2013) }\end{array}$ & Singapura & $\begin{array}{l}304 \\
\text { responden }\end{array}$ & $21-80$ tahun & - & - & $\begin{array}{l}\text { Cross sectionall alat } \\
\text { yang digunakan adalah } \\
\text { kuesioner dan } \\
\text { glukometer }\end{array}$ & $\begin{array}{l}\text { Pengobatan komplementer yang umum } \\
\text { digunakan oleh sampel saat melakukan } \\
\text { rawat jalan adalah suplemen gizi, obat } \\
\text { herbal cina dan terapi pijat. Sumber } \\
\text { informasi pasien mengenai CAM adalah } \\
44,2 \% \text { dari teman, dari pasangan dan } \\
\text { keluarga } 38 \% \text {. } \\
\text { Factor yang mempengaruhi pasien } \\
\text { menggunakan pengobatan komplementer } \\
\text { adalah gender dengan } \mathrm{P} \text { value = } 0.049 \text {. } \\
\text { pemasukan rumah tangga } \mathrm{P}= \\
0.048 \text { dan frekuensi kontrol gula darah } \mathrm{P}= \\
0.036 \text { perlu dilakukan peningkatan } \\
\text { profesionalitas } \\
\text { tenaga kesehatan mengenai }\end{array}$ \\
\hline
\end{tabular}




\begin{tabular}{|c|c|c|c|c|c|c|c|}
\hline & & & & & & & $\begin{array}{l}\text { kemampuan memberikan edukasi dan } \\
\text { pelayanan terapi komplementer pada } \\
\text { pasien rawat } \\
\text { jalan. }\end{array}$ \\
\hline $\begin{array}{l}\text { How Effective } \\
\text { is Swedish } \\
\text { Massage on } \\
\text { Blood } \\
\text { Glucose } \\
\text { Level in } \\
\text { Children with } \\
\text { Diabetes } \\
\text { Mellitus } \\
\text { Sajedi, et. } \\
\text { Al.,(2011) }\end{array}$ & Iran & $\begin{array}{l}38 \text { sampel } \\
19 \text { kelompok } \\
\text { kasus dan } 19 \\
\text { kelompok } \\
\text { kontrol }\end{array}$ & $\begin{array}{l}\text { Anak- } \\
\text { anak } \\
\text { usia } \\
6-12 \\
\text { tahun }\end{array}$ & $\begin{array}{l}\text { Diberikan } \\
\text { intervensi } \\
\text { swedish massage } \\
3 \text { kali seminggu } \\
\text { selama } 15 \text { menit. } \\
\text { Intervensi } \\
\text { diberikan selama } \\
3 \text { bulan }\end{array}$ & $\begin{array}{l}\text { Tidak } \\
\text { diberikan } \\
\text { intervensi } \\
\text { swedish } \\
\text { masage } \\
\text { hanya } \\
\text { diberikan } \\
\text { intervensi } \\
\text { yang } \\
\text { biasa } \\
\text { dilakukan } \\
\text { pada } \\
\text { umumnya }\end{array}$ & $\begin{array}{l}\text { RCT (random } \\
\text { control trial). } \\
\text { Lembar observasi } \\
\text { swedish massage } \\
\text { dan kuesioner }\end{array}$ & $\begin{array}{l}\text { Swedish massage efektif memberikan } \\
\text { efek penurunan kadar glukosa darah } \\
\text { pada anak dengan diabetes melitus } \\
\text { dengan nilai } P=0.00\end{array}$ \\
\hline $\begin{array}{l}\text { Complementar } \\
\text { y Therapies } \\
\text { Used Among } \\
\text { Adult Patients } \\
\text { with Type } 2 \\
\text { Diabetes } \\
\text { Mellitus in } \\
\text { Aceh, } \\
\text { Indonesia } \\
\text { Niswah et al } \\
\text { (2014) }\end{array}$ & Indonesia & $\begin{array}{l}154 \text { sampel } \\
\text { Laki-laki } 65 \\
\text { dan } \\
\text { perempuan } \\
89\end{array}$ & $\begin{array}{l}\text { Dewasa } \\
\text { usia } \\
30 \\
\text { hingga } \\
\text { lebih } \\
\text { dari } 70 \\
\text { tahun }\end{array}$ & - & - & $\begin{array}{l}\text { Cross } \\
\text { sectional/kuesion } \\
\text { er }\end{array}$ & $\begin{array}{l}\text { Favorit sampel menggunakan pengobatan } \\
\text { herbal mencapai } 100 \% \text {. Intervensi mind } \\
\text { body } 94,2 \% \text {. } 100 \% \text { Sampel mempercayai } \\
\text { bahwa obat herbal dapat menurunkan } \\
\text { kadar glukosa darah, menyehatkan tubuh } \\
76,6 \% \text { dan dapat mengatasi gejala DM } \\
35,7 \% . \text { Informasi mengenai pengobatan } \\
\text { herbal } 98,7 \% \text { di dapatkan dari relasi dan } \\
\text { teman, } 89 \% \text { mengetahui sendiri, } \\
\text { semantara informasi dari market } \\
\text { local } 36,4 \% \text {. }\end{array}$ \\
\hline
\end{tabular}




\begin{tabular}{|c|c|c|c|c|c|c|c|}
\hline $\begin{array}{l}\text { Physiological } \\
\text { Changes } \\
\text { Following } \\
\text { Thermomech } \\
\text { anical } \\
\text { Massage inn } \\
\text { a Population } \\
\text { of } \\
\text { Hypertensive } \\
\text { Patient and/or } \\
\text { Type II } \\
\text { Diabetic }\end{array}$ & $\begin{array}{l}\text { South } \\
\text { Korea }\end{array}$ & 238 sampel & $\begin{array}{l}>60 \\
\text { tahun }\end{array}$ & $\begin{array}{l}\text { Terdapat tiga } \\
\text { kelompok. } \\
\text { Kelompok } \\
\text { pertama adalah } \\
\text { kelompok pasien } \\
\text { dengan } \\
\text { hipertensi, } \\
\text { kelompok kedua } \\
\text { pasien dengan } \\
\text { diabetes tipe II } \\
\text { dan kelompok } \\
\text { ketiga adalah } \\
\text { pasien yang } \\
\text { menderita diabetes } \\
\text { tipe II }\end{array}$ & - & $\begin{array}{l}\text { Quasy } \\
\text { eksperiment } \\
\text { dengan pre post } \\
\text { test/kuesioner, } \\
\text { spimomanometer, } \\
\text { glukometer. }\end{array}$ & $\begin{array}{l}\text { Thermomechanical massage dapat } \\
\text { menurunkan tekanan darah dengan } \mathrm{P} \\
\text { value = 0.00; glukosa darah pasien dengan } \\
\text { diabetes mengalami penurunan setelah } \\
\text { dilakukan perlakuan dengan } \mathrm{P} \text { value = } \\
0.00 ; \text { kelompok dengan } \\
\text { diabetes dan hipertensi signifikan }\end{array}$ \\
\hline
\end{tabular}




\begin{tabular}{|c|c|c|c|c|c|c|c|}
\hline So, et al.,(2004) & & & & $\begin{array}{l}\text { dan hipertensi. Jumlah } \\
\text { sampel kelompok } \\
\text { hipertensi 16, kelompok } \\
\text { diabetes melitus tipe II } \\
12 \text { dan kelompok } \\
\text { sampel menderita } \\
\text { diabetes tipe II dan } \\
\text { hipertensi berjumlah } 19 .\end{array}$ & & & $\begin{array}{l}\text { mengalami penurunan } \\
\text { tekanan darah dan } \\
\text { penurunan kadar glukosa } \\
\text { darah dengan } P \text { value }< \\
0.05\end{array}$ \\
\hline $\begin{array}{l}\text { Effects of } \\
\text { massage on } \\
\text { physiological } \\
\text { restoration, } \\
\text { perceived } \\
\text { recovery, and } \\
\text { repeated } \\
\text { sports } \\
\text { performance } \\
\text { Hemmin } \\
\text { gs, et } \\
\text { al.,(2000) }\end{array}$ & $\begin{array}{l}\text { United } \\
\text { Kingdom }\end{array}$ & $\begin{array}{l}\text { Di artikel } \\
\text { tidak } \\
\text { disebutkan } \\
\text { berapa } \\
\text { jumlah } \\
\text { sampel }\end{array}$ & $\begin{array}{l}\text { Di artikel } \\
\text { juga tidak } \\
\text { disebutka } \\
\text { n berapa } \\
\text { usia dari } \\
\text { sampel }\end{array}$ & $\begin{array}{l}\text { Tidak disebutkan berapa } \\
\text { jumlah kelompok } \\
\text { intervensi. }\end{array}$ & $\begin{array}{l}\text { Tidak } \\
\text { disebutkan } \\
\text { berapa jumlah } \\
\text { kelompok } \\
\text { kontrol namun } \\
\text { kelompok } \\
\text { kontrol } \\
\text { menjalankan } \\
\text { passive rest } \\
\text { intervensi. }\end{array}$ & $\begin{array}{l}\text { Two occasions in a } \\
\text { counter balance } \\
\text { design/ kuesioner, } \\
\text { sigmomanometer, } \\
\text { glukometer dan } \\
\text { pengukur asam } \\
\text { laktat dalam darah. }\end{array}$ & $\begin{array}{l}\text { Tidak ada perbedaan } \\
\text { signifikan antara group } \\
\text { setelah dilakukan intervensi } \\
\text { namun terdapat penurunan } \\
\text { selisi antar group dengan nilai } \\
\mathrm{P}<0.05 \text {; intervensi pijat dapat } \\
\text { meningkatkan perbaikan } \\
\text { persepsi pasien dengan nilai } \\
\mathrm{P}<0.01 \text {; tidak ada perbedaan } \\
\text { kandungan laktat dan glukosa } \\
\text { darah dari intervensi dan } \\
\text { pasien rest intervensi. Namun } \\
\text { terdapat signifikasi kadar } \\
\text { glukosa darah dan laktat } \\
\text { sebelum dan sesudah pijat } \\
\text { dengan nilai } \\
\mathrm{P}<0.05\end{array}$ \\
\hline
\end{tabular}

